This item was submitted to Loughborough's Research Repository by the author.

Items in Figshare are protected by copyright, with all rights reserved, unless otherwise indicated.

\title{
Advanced fuel cell based on Perovskite La-SrTiO3 semiconductor as the electrolyte with superoxide-ion conduction
}

PLEASE CITE THE PUBLISHED VERSION

https://doi.org/10.1021/acsami.8b10087

\section{PUBLISHER}

(c) American Chemical Society

\section{VERSION}

AM (Accepted Manuscript)

\section{PUBLISHER STATEMENT}

This document is the Accepted Manuscript version of a Published Work that appeared in final form in ACS Applied Materials and Interfaces, copyright $@$ American Chemical Society after peer review and technical editing by the publisher. To access the final edited and published work see https://pubs.acs.org/doi/10.1021/acsami.8b10087.

\section{LICENCE}

CC BY-NC-ND 4.0

\section{REPOSITORY RECORD}

Chen, Gang, Bin Zhu, Hui Deng, Yadan Luo, Wenkang Sun, Hailiang Liu, Wei [Hubei University] Zhang, et al.. 2018. "Advanced Fuel Cell Based on Perovskite La-srtio3 Semiconductor as the Electrolyte with Superoxideion Conduction”. figshare. https://hdl.handle.net/2134/34765. 


\section{Advanced fuel cell based on perovskite $\mathrm{La}_{-} \mathrm{SrTiO}_{3}$}

\section{semiconductor as the electrolyte with super oxide-ion conduction}

Gang Chen ${ }^{\mathrm{a}, \mathrm{c}}$, Bin Zhu ${ }^{\mathrm{b}, \mathrm{d} *}$, Hui Deng ${ }^{\mathrm{b}}$, Yadan Luo ${ }^{\mathrm{a}}$, Wenkang Sun ${ }^{\mathrm{a}}$, Hailiang Liu ${ }^{\mathrm{a}}$, Wei Zhang ${ }^{\mathrm{b}}$, Xunying Wang ${ }^{\mathrm{b}}$, Yumin Qian ${ }^{\mathrm{a}}$, Xianwei Hu ${ }^{\mathrm{a}}$, Shujiang Geng ${ }^{\mathrm{a}, \mathrm{c}}$, Jung-Sik Kim ${ }^{\mathrm{d}}$

a. School of Metallurgy, Northeastern University, Shenyang, 110819, China.

b. Hubei Collaborative Innovation Center for Advanced Organic Chemical Materials, Key Laboratory of Ferro \& Piezoelectric Materials and Devices of Hubei Province, Faculty of Physics and Electronic Science, Hubei University, Wuhan, Hubei 430062, P. R. China

c. Liaoning Key Laboratory for Metallurgical Sensor and Technology, Northeastern University, Shenyang, 110819, China.

d. Department of Aeronautical \& Automotive Engineering, Loughborough University, Loughborough LE11 3TU, United Kingdom.

*Corresponding author. E-mail: binzhu@kth.se 


\begin{abstract}
A solid oxide fuel cell's (SOFC) performance is largely determined by the ionic-conducting electrolyte. A novel approach is presented for using the semiconductor perovskite $\mathrm{La}_{0.25} \mathrm{Sr}_{0.75} \mathrm{TiO}_{3}$ (LST) as the electrolyte by creating surface superionic conduction, and the authors show that the LST electrolyte can deliver superior power density, $908.2 \mathrm{~mW} \cdot \mathrm{cm}^{-2}$ at just $550{ }^{\circ} \mathrm{C}$. The prepared LST materials formed a heterostructure including an insulating core and a super ionic conducting surface layer. The rapid ion transport along the surfaces or grain boundaries was identified as the primary means of oxygen ion conduction. The fuel cell-induced phase transition was observed from the insulating LST to a super $\mathrm{O}^{2-}$ conductivity of $0.221 \mathrm{~S} \cdot \mathrm{cm}^{-1}$ at $550{ }^{\circ} \mathrm{C}$, leading to excellent current and power outputs.
\end{abstract}

Keywords: Solid oxide fuel cell, La substituted $\mathrm{SrTiO}_{3}$, superionic conduction, core-shell heterostructure, oxygen vacancies 


\section{Introduction}

A SOFC is a promising device for direct conversion of the energy stored in chemical fuels into electricity. Lowering its operating temperature is a universal R\&D challenge for enabling them to meet the demands of commercialization. ${ }^{1}$ Over an extended period, commercialization of SOFCs has been delayed by its associated manufacturing and maintaining costs due to the high operation temperature $\left(700-1000{ }^{\circ} \mathrm{C}\right)$. The main ionic transport mechanism of the SOFC electrolyte materials, such as $8 \mathrm{~mol} . \% \quad \mathrm{Y}_{2} \mathrm{O}_{3}$ stable $\mathrm{ZrO}_{2}$ (YSZ), gadolinia doped ceria (GDC) and strontium- and magnesium- doped lanthanum gallate (LSGM), is bulk diffusion, which is primarily affected by the structural doping and operating temperatures. ${ }^{2-5}$ For low-temperature operations, various advanced thin film technologies have been used to fabricate thin YSZ electrolyte devices; in parallel, new materials that address the problems caused by high-temperature operation have also been attractive. ${ }^{6-9}$. For existing materials, the use of advanced thin film technologies greatly increases the cost and negatively affects the long-term stability of the SOFC stack. ${ }^{8,} 10-12$ Therefore, new electrolyte materials for LT-SOFCs are highly necessary but the structural doping approach and bulk ionic conduction mechanism present ever stronger challenges without definitive solutions. In recent years, the interfacial diffusion phenomenon has attracted intense attention. ${ }^{13-15}$. Barriocanal et al. reported a colossal ionic conductivity at the interfaces of epitaxial 
$\mathrm{ZrO}_{2}: \mathrm{Y}_{2} \mathrm{O}_{3} / \mathrm{SrTiO}_{3}$ (YSZ/STO) heterostructures. This is the first report on the great ionic conductivity enhancement for the YSZ in a typical semiconductor (STO) and ionic conductor YSZ composite material. The eight orders of magnitude enhancement of the ionic conductivity of YSZ was considered to represent the values that enable the practical application of the material in SOFCs approaching room temperature. ${ }^{13}$. Lee et al. reported that the ionic conductivity of $20 \mathrm{~nm}$ diameter YSZ nanocolumns that are strain-coupled to thick epitaxial STO matrix nanocomposite films is two orders of magnitude higher than that of the plain YSZ films. ${ }^{14}$ Maier showed that the ionic transport properties are also drastically changed at the interfaces and may dominate the ionic conductivity of the whole material. ${ }^{15}$. Haverkate et al. found that decreasing the dimensions of heterogeneous mixtures of ionic conductors toward the nanoscale results in ionic conduction enhancements caused by the increased influence of the interfacial space-charge regions. ${ }^{16}$ Very recently, semiconductors alone have been introduced as the electrolytes for advanced LT-SOFCs. Considering $\mathrm{Li}_{\mathrm{x}} \mathrm{Co}_{0.5} \mathrm{Al}_{0.5} \mathrm{O}_{2}$, at $500^{\circ} \mathrm{C}$, proton conductivity can reach $0.1 \mathrm{~S} \cdot \mathrm{cm}^{-1}$ and when used as the electrolyte can achieve $180 \mathrm{~mW} \cdot \mathrm{cm}^{-2}$ at $525{ }^{\circ} \mathrm{C} ;{ }^{17}$ a perovskite $\mathrm{SmNiO}_{3}$ used as the electrolyte for a fuel cell device also successfully delivered a power density $225 \mathrm{~mW} \cdot \mathrm{cm}^{-2}$ at $500{ }^{\circ} \mathrm{C}$, respectively. ${ }^{18}$. Both have reported very interesting super-protonic conduction transitions. When applied in the fuel cell environment, the $\mathrm{Li}_{\mathrm{x}} \mathrm{Co}_{0.5} \mathrm{Al}_{0.5} \mathrm{O}_{2}$ experienced a super-proton conduction transition by incorporating the $\mathrm{H}^{+}$into 
its interlayer structures; in the $\mathrm{SmNiO}_{3}$ (SNO) case, it experienced a Mott transition from a metallic conduction transforming into a proton conductor, H-SNO. This is caused by strong correlation due to the Coulombic interactions of electrons. ${ }^{18}$ These semiconductors, $\mathrm{Li}_{\mathrm{x}} \mathrm{Co}_{0.5} \mathrm{Al}_{0.5} \mathrm{O}_{2}$ and $\mathrm{SNO}$ as the electrolyte fuel cells in a freestanding membrane geometry are the same as reported for the single layer fuel cell (SLFC). ${ }^{19-22}$. The SLFC or electrolyte-free fuel cell (EFFC) concept was demonstrated and good fuel cell performance has been achieved in a wide range of materials commonly consisting of a semiconductor and an ionic conducting material. ${ }^{19-22}$

Reviewing the aforementioned new research and development on SOFCs, the semiconductors and their heterostructure materials deserve much more attentions and R\&D efforts. Here, we report a new promising perovskite $\mathrm{La}_{0.25} \mathrm{Sr}_{0.75} \mathrm{TiO}_{3}$ (LST). Unlike the SNO, the LST is almost an insulator in the as-prepared state and becomes a high oxide-ion conductor under the fuel cell conditions, resulting in the excellent fuel cell performance of $908.2 \mathrm{~mW} \cdot \mathrm{cm}^{-2}$ at $550{ }^{\circ} \mathrm{C}$. This greatly enhanced electrical property is not attributed to a structural change but to a mechanism related to the grain boundaries and surface states by forming a heterostructured semiconducting core with a superionic surface layer.

\section{Experimental}

\subsection{Synthesis of LST}

$\mathrm{La}_{0.25} \mathrm{Sr}_{0.75} \mathrm{Ti}_{1} \mathrm{O}_{3}$ powders were synthesized by the sol-gel method. ${ }^{23} \mathrm{La}_{2} \mathrm{O}_{3}$ (99.99\%), $\mathrm{SrCO}_{3}$ (98\%), titanium (+IV) isopropoxide $\mathrm{Ti}\left[\mathrm{OCH}\left(\mathrm{CH}_{3}\right)_{2}\right]_{4}(98 \%)$, 
$\mathrm{Al}\left(\mathrm{NO}_{3}\right)_{3} \cdot 9 \mathrm{H}_{2} \mathrm{O} \quad$ (99\%), $\quad \mathrm{Sc}\left(\mathrm{NO}_{3}\right)_{3} \quad(99.999 \%), \quad \mathrm{Ga}\left(\mathrm{NO}_{3}\right)_{3} \cdot 9 \mathrm{H}_{2} \mathrm{O} \quad$ (99.99\%), ethylene glycol, citric acid and nitric acid were used as the raw materials. First, $\mathrm{La}_{2} \mathrm{O}_{3}$. powder was pre-calcined at $1000{ }^{\circ} \mathrm{C}$ to remove the adsorbed moisture. $\mathrm{Ti}\left[\mathrm{OCH}\left(\mathrm{CH}_{3}\right)_{2}\right]_{4}$ was dissolved in ethylene glycol (volume ratio: 1/4) under gentle magnetic stirring. Citric acid was then added into the $\operatorname{Ti}\left[\mathrm{OCH}\left(\mathrm{CH}_{3}\right)_{2}\right]_{4}$ and ethylene glycol solution with a $\mathrm{Ti}$ cation and citric mole ratio of $1 / 4$. The pre-calcined $\mathrm{La}_{2} \mathrm{O}_{3}$ and $\mathrm{SrCO}_{3}$ were dissolved in nitric acid. The solutions with stoichiometric ratios of the $\mathrm{Ti}^{4+}$ aqueous solution, $\mathrm{La}$ and $\mathrm{Sr}$ nitric acid were mixed under gentle stirring for $12 \mathrm{~h}$. The precursor solution was heated and stirred continuously for several hours to evaporate the water and to form brown gels. The gels were then dried and pyrolyzed on a hot plate at $530{ }^{\circ} \mathrm{C}$ in a ceramic crucible for $2 \mathrm{~h}$. The pyrolyzed LST ash was sintered at $1200{ }^{\circ} \mathrm{C}$ in air for 2 hours.

\subsection{Fabrication of fuel cell}

The as-prepared LST as the electrolyte which was sandwiched between two Ni-foam pasted by $\mathrm{Ni}_{0.8} \mathrm{Co}_{0.15} \mathrm{Al}_{0.05} \mathrm{LiO}_{2}$ used as the electrode and current connector. The sandwich was then pressed under a uniaxial load of $280 \mathrm{MPa}$ to form a symmetrical single fuel cell device. In the fuel cell test process, the Ni-foam coated with NCAL played the role of the anode and cathode under different gas flows. The cell has a diameter of $13 \mathrm{~mm}$ and a thickness of 1.5 $\mathrm{mm}$ with the effective area of $0.64 \mathrm{~cm}^{2}$.

\subsection{Material characterizations}


The phase structure of the as-prepared LST powder material was characterized using an X-ray-diffractometer. JEM-ARM200F STEM fitted with a STEM Cs corrector was used to perform the HAADF imaging. The surface characteristics of the LST powder were analyzed using X-ray photoelectron spectroscopy (XPS) and Raman spectrometry. The XPS spectra were recorded on a Thermo scientific Escalab 250Xi XPS system with a monochromatic twin anode $\mathrm{Al} / \mathrm{Mg} \mathrm{X}$-ray source. The binding energies and oxidation states were obtained from high-resolution scans. The Raman spectra were recorded on a HORIBA JOBIN YVON HR800 with the wavelength of $488 \mathrm{~nm}$. Micro-structures of the cells were characterized with FE-SEM. The FTIR spectra were recorded by a Nicolet-380 (Thermo, USA) spectrophotometer with $4 \mathrm{~cm}^{-1}$ resolution in the range of $4000-400$ wavenumbers $\left(\mathrm{cm}^{-1}\right)$. TGA was performed between 30 and $1200{ }^{\circ} \mathrm{C}$ using an SDT-Q600 instrument (TA, USA).

\subsection{Electrochemical measurements}

Electrochemical performance tests of the cells with different LST electrolytes were performed in humidified $\mathrm{H}_{2}$ in the $450-550{ }^{\circ} \mathrm{C}$ temperature range. Air was supplied as the oxidant. The flow rate of $\mathrm{H}_{2}$ and air to each side of the cells was $100 \mathrm{~mL} \cdot \mathrm{min}^{-1}$ at the pressure of $1.5 \mathrm{~atm}$. The impedance of the cells was measured between $0.1 \mathrm{~Hz}$ and $1 \mathrm{MHz}$ using a Gamry Reference 3000 electrochemical workstation with the AC voltage with the amplitude of $10 \mathrm{mV}$ 
under open-circuit conditions. The IV curves of the cells were measured using computerized instruments (IT8511+ 120 V/30 A/150 W).

\section{Results and discussion}

Figures S1 and 1(a)-(b) show the XRD pattern and low-magnification STEM image and the HAADF-STEM image of the LST powder. The XRD pattern with the indexed diffraction peaks can be identified as a cubic perovskite structure. The contrast of the high-angle annular dark-field imaging (HAADF) image is very powerful, enabling the study of the local environments of the heavy atoms. The average particle size of the LST powder is $100-400 \mathrm{~nm}$, as shown in Fig. 1(a). An HAADF-STEM image of the surface area of the LST powder is shown in Fig. 1(b). The blue and green circles in Fig. 1(b) represent the A site and $\mathrm{B}$ site cations, respectively, of the $\mathrm{LST} \mathrm{ABO}_{3}$ structure. The average distance between two A-site cations was approximately $0.39 \mathrm{~nm}$, consistent with the previously reported lattice parameter of LST. ${ }^{24}$. According to the principle of HAADF-STEM Z-contrast imaging, the layer with little highlighted cation Z-contrast imaging at the surface of the LST in Fig. 1(b) is identified as an amorphous layer. The thickness of this amorphous layer is approximately $1 \mathrm{~nm}$. The bulk core and amorphous shell of the LST particles constitute a very unique core-shell structure. Here, the core- shell structure of the LST particle can be considered as a novel heterostructure as discussed below. As shown in Fig. 1(c), continuous interfaces were formed when a large number of particles were compacted together. Such a continuous space charge 
area in the compact LST interfacial layer will become the transport channel for the ions. In solid state ionics, a space charge region is widely believed to exist at the overlapping part of the interface between two ionic conductors or at the surface of the conductor. ${ }^{13-16,25-27}$. Such space charge regions presumably exhibit a very high ionic conductivity.

The authors developed a symmetrical fuel cell using the LST as the electrolyte. Fig. 1(d) shows the diagram of the symmetrical device with the $\mathrm{Ni}$-NCAL/LST/NCAL-Ni structure, where Ni-NCAL is a semiconductor $\mathrm{Ni}_{0.8} \mathrm{Co}_{0.15} \mathrm{Al}_{0.05} \mathrm{LiO}_{2}$ (NCAL) pasted onto $\mathrm{Ni}$-foam as the electrode. The electrochemical performance of as-fabricated cell was measured in dry $\mathrm{H}_{2}$ at the temperature range of $450 \sim 550{ }^{\circ} \mathrm{C}$ with air as the oxidant. The I-V and I-P characteristics of the cell are shown in Fig. 2. Peak power densities of 908.2, 548.4 and $297.2 \mathrm{~mW} \cdot \mathrm{cm}^{-2}$. were obtained at 550, 500 and $450{ }^{\circ} \mathrm{C}$, respectively. In a traditional SOFC, such electrochemical performance is typically obtained in a cell with a very thin electrolyte film. ${ }^{8}$ The cell shows such high electrochemical performance at low temperature, the Ni-NCAL composite electrodes play a very important role. The details of the ORR and HOR mechanisms of the foam Ni-NCAL composite electrodes have been reported in our previous study. ${ }^{28}$. What is more interesting is why LST can be used as an electrolyte and has a high ionic conductivity.

It is important to note that although LST is an electronic conductor in a reducing atmosphere in the traditional sense, ${ }^{23,29-30}$ the open circuit voltages of the cell are 
1.128, 1.141 and 1.212 at 550, 500 and $450{ }^{\circ} \mathrm{C}$, respectively, in agreement with the values calculated using the Nernst equation. ${ }^{24}$. Fig. 3 shows the OCV changes with time after $\mathrm{H}_{2}$ and air were supplied on two sides of the cell with the LST electrolyte. The OCV rapidly increased within $80 \mathrm{~s}$ after supplying $\mathrm{H}_{2}$ /air. The OCV was close to $1.1 \mathrm{~V}$ in a few minutes. Such a high OCV indicates that no obvious internal short circuit induced by the electrical conduction of LST was observed.

Fig. 4 shows the SEM images of the cross section of the symmetrical cell with the Ni foam-NCAL/LST/NCAL-Ni foam structure prepared in this study. The Ni-NCAL electrode and the LST electrolyte thicknesses are both approximately $0.5 \mathrm{~mm}$. The NCAL electrode shows a porous structure. From Fig. 4, one can see that the NCAL is completely embedded in the $\mathrm{Ni}$ foam. Ni foam, NCAL and LST three materials constitute the active region of the electrode reactions. The LST electrolyte is dense, so that it does not allow hydrogen permeating through it in the present case. The high OCV shown in Fig. 3 confirmed this point. Unlike the electrolyte in traditional SOFCs, LST electrolyte did not undergo the densification process with sintering at high temperature. The LST in the electrolyte still maintains the shape of the powder particles. We refer to such a LST electrolyte as a gas-tight layer even without high temperature densification.

As an electron conductor, the behavior of LST has some similarity to the SNO case, but is not due to a Mott transition because our LST material is initially shows a very low conductivity of $10^{-6} \mathrm{~S} \cdot \mathrm{cm}^{-1}$. whereas SNO shows metallic behavior with the electrical conductivity of $1000 \mathrm{~S} \cdot \mathrm{cm}^{-1}{ }^{18}$. Zhou et al. demonstrated a filling-controlled 
Mott transition on SNO to avoid the electron internal short-circuit problem in an SOFC due to the formation of an electronic insulating proton-conducting $\mathrm{H}-\mathrm{SNO}$ layer. ${ }^{18}$ A different mechanism occurs in our case because the almost insulating LST experienced by a $\mathrm{H}_{2} /$ air induced a phase transition to a super oxide-ion conducting phase, as will be further discussed below.

To investigate the electrical properties of the LST in the fuel cell, EIS measurements were conducted at $550{ }^{\circ} \mathrm{C}$ in different atmospheres, in the following order: in air/air, $\mathrm{H}_{2}$ /air, $\mathrm{N}_{2} / \mathrm{N}_{2}$ and air/air. Air was first supplied on both sides of the cell for the EIS measurement, with the results shown in Fig. 5(a). $\mathrm{H}_{2}$ flowed into one side of the cell to replace the air after the EIS measurement in air/air. The EIS measurement was again performed after flowing $\mathrm{H}_{2}$ for $10 \mathrm{~min}$. The EIS of the cell in a $\mathrm{N}_{2} / \mathrm{N}_{2}$ atmosphere were measured after both the $\mathrm{H}_{2}$ and air in the cell were purged by pure $\mathrm{N}_{2}$ for $1 \mathrm{~h}$. Finally, the $\mathrm{N}_{2}$ in both sides of the cell was replaced by air for another $1 \mathrm{~h}$, then completing the final EIS measurement in air/air. The EIS results of the cell in different atmospheres are shown in Fig. 5(b).

Examination of Fig. S3 shows that the NCAL exhibits high electronic (hole-type in the air) conduction with the electrical conductivity of 9.8 $\mathrm{S} \cdot \mathrm{cm}^{-1} .{ }^{31}$ Thus, the high resistance of the cell in the air/air atmosphere, as observed in Fig. 5(a), should be due to the LST electrolyte. The equivalent circuit simulations (see Fig. S4) show that the EIS in air/air displays electronic and ionic conduction effects. The calculation shows that the electronic 
resistance of the cell in air is $27580 \Omega \cdot \mathrm{cm}^{2}$ and the ionic resistance of the LST electrolyte is $10030 \Omega \cdot \mathrm{cm}^{2}$. Fig. 5(b) displays the impedance spectra of the cell with $\mathrm{H}_{2}$ /air, $\mathrm{N}_{2} / \mathrm{N}_{2}$ and based to air/air flowed sequentially. The intercept of the impedance arc on the real axis in Fig. 5(b) at high frequencies represents the ohmic resistance (Ro) of the LST because the other participating resistances of the NCAL-Ni foam electrodes and some contact resistance associated with the device can be ignored due to their much high conductivities compared to the LST. It can be seen that the resistance of the cell arising from the LST electrolyte decreased from $37610 \Omega \cdot \mathrm{cm}^{2}$ to approximately $0.52 \Omega \cdot \mathrm{cm}^{2}$. under the $\mathrm{H}_{2}$ /air for $10 \mathrm{~min}$. Such a large resistance change of the cell indicates that the fuel cell atmosphere plays a key role in inducing some phase transition. Turning to the case of $\mathrm{N}_{2} / \mathrm{N}_{2}$, the Ro and polarization resistance (Rp) of the LST were changed to $1.87 \Omega \mathrm{cm}^{2}$ and $3.45 \Omega \cdot \mathrm{cm}^{2}$. Finally, returning to air/air after the $\mathrm{N}_{2}$ was replaced by air for $1 \mathrm{~h}$, the Ro and Rp of the LST decreased again to approximately $1.12 \Omega \cdot \mathrm{cm}^{2}$ and $1.45 \Omega \cdot \mathrm{cm}^{2}$, respectively. These results correspond to the LST conductivities of $0.221 \mathrm{~S} \cdot \mathrm{cm}^{-1}$ in $\mathrm{H}_{2} /$ air and 0.045 $\mathrm{S} \cdot \mathrm{cm}^{-1}$ for back to air/air but starting from $1.35^{*} 10^{-6} \mathrm{~S} \cdot \mathrm{cm}^{-1}$ first in air/air. It may be noticed that this phase transition is not reversible. The significantly reduced total resistance of the cell going back to the air/air indicates that after undergoing a transition during the fuel cell measurement the LST remains a good oxygen ion conductor. It is reasonable to assume that the shell layer transforms into superionic conduction channels because we found that the shell 
layer is filled by oxygen vacancies, indicating a superionic conducting phase, which was analyzed by XPS, FITIR and Raman after the fuel cell operation as discussed below.

To further determine the oxide-ion conducting property for the LST samples, the authors utilized the benchmark oxide-ion conductor, e.g., gadolinium doped ceria (GDC) as the standard. Fig. 6 shows the IV-IP curve of the cell with the bi-layered LST/GDC electrolyte and the corresponding schematic of the cell. This cell was fabricated to replace the LST electrolyte using the LST/GDC bi-layer in the same way as the LST cell. Here, the oxide-ion GDC electrolyte acts as the $\mathrm{O}^{2-}$ filter that can only allow the $\mathrm{O}^{2-}$ transport through the LST. It was observed that the OCV of the bi-layered LST/GDC electrolyte cell is $1.11 \mathrm{~V}$. The peak power density of the bi-layered $\mathrm{LST} / \mathrm{GDC}$ cell is $543.1 \mathrm{~mW} \cdot \mathrm{cm}^{-2}$, which is indeed high for a cell with such a thick electrolyte layer with the thickness of $1.0 \mathrm{~mm}$. The GDC is well-known as an oxygen ion conductor so the authors argue that the remarkable peak power density may be attributed to the capability of the LST to conduct oxygen ions. An additional experiment was conducted to prove this hypothesis. We observed that the color of the allochroic silica gel changed after the cell's anode exhaust gas passed through it. This is because of the water formation at the anode side. This strongly indicates that the LST electrolyte prepared in present case can conduct oxygen ions. It should be noted that these results still can not exclude 
whether LST electrolyte has proton conduction characteristics, which needs further study in future research.

Notably, the ionic conductivity of the LST calculated from the I-V curve of the cell shown in Fig. 2 is approximately $0.221 \mathrm{~S} \cdot \mathrm{cm}^{-1}$ at $550{ }^{\circ} \mathrm{C}$. This indicates an ionic conductivity of the LST which is much higher than that of traditional oxygen ion conductors (SDC, GDC, LSGM, etc.) at the same temperature. ${ }^{3-5}$ It has been widely reported that LST is an n-type electronic semiconductor in a reducing atmosphere with a very poor ionic conductivity. ${ }^{32}$ Compared to the conventional structural doped materials, e.g., YSZ, SDC, etc., bulk conduction and diffusion is unlikely to be the primary oxygen ion diffusion mechanism in the LST. We believe that the main path for the oxygen ion transport should be attributed to the space charge area between the LST particles, as indicated in Fig. 1.

XPS analysis further discovered that the non-lattice oxygen existed in the surface of LST powders treated in different conditions. Two types of O binding states were identified in Fig. 7(a), according to the literature. ${ }^{33-35}$. The stronger peak at approximately $529.05 \mathrm{eV}$ is identified as the $\mathrm{O}^{2-}$. ions related to the lattice oxygen in the perovskite structure of LST (represented by the green dashed line and denoted as lattice oxygen). The peak at approximately $531 \mathrm{eV}$ is assigned to the oxygen ions in the oxygen vacancies region and an intermediate oxidation state of oxygen, $\mathrm{O}^{\mathrm{x}-} \cdot(0<\mathrm{x}<2)$, and it may be related to the hydroxyl $(\mathrm{OH})$ groups. One may observe that the amount of $\mathrm{OH}$ groups and 
the oxygen vacancies in the LST powder after reduction in $\mathrm{H}_{2}$ increased slightly compared to that in the raw powder (see Fig. 7 and Table S2). However, the amount of $\mathrm{OH}$ groups and oxygen vacancies increased significantly in the LST after the fuel cell measurement in $\mathrm{H}_{2}$ /air conditions. FTIR spectra and TGA studies that are shown in Fig. S6 support this interpretation. The Raman analysis on variation of the surface oxygen vacancy concentrations in these LST samples is consistent with the XPS fitting result (see Fig. S7 and Table S3).

Fig. 8 shows the HRTEM images of LST powder before and after performance test. A lattice disorder layer with thickness of $1.2 \mathrm{~nm}$ was observed for the raw LST powder in Fig. 8(a), which is identified as an amorphous layer. The structure of the raw LST powder with such amorphous layer is considered as a novel core-shell structure. From Fig. 8(b), it can be seen that the amorphous layer thickness of the LST powder scraped from the cell after the fuel cell measurements is increased. After the fuel cell performance test, the crystallization phenomenon appeared inside the amorphous layer of LST particles. Combined with the XPS results of Fig. 7(c), we can see that the oxygen vacancy concentration in the amorphous layer of LST scraped from the cell after the fuel cell measurements should be significantly increased. The EIS results in Fig. 5(a) and (b) show that the LST electrolyte has undergone a phase transition in the fuel cell test atmosphere, from a similar insulating phase to a very high ionic conductivity phase. From the HRTEM results of Fig. 8, we can 
see that the phase transition of LST electrolyte should happen on the surface of LST particles. The partially crystallized and widened amorphous layers with large amounts of oxygen vacancies become the ion fast conduction channels of LST electrolytes. From the EIS test results of Fig. 5(a) and (b), this phase transition is irreversible. Once a phase of high ionic conductivity is formed on the surface of LST in the fuel cell test atmosphere, the phase will not disappear in the air.

It is well known that XPS and Raman are both sensitive to the surface of the material. Combined with the HRTEM results shown in Fig. 8, it can be suggested that some oxygen vacancies detected in the LST powder should primarily exist in the amorphous layer on the LST surface. The amorphous layer with the oxygen vacancies and an inner bulk LST constitutes the core-shell structure. The XPS and HRTEM results shown in Fig. 7(b) and Fig. 8(b) indicate that $\mathrm{H}_{2}$ reduction alone cannot lead to the significant change of the surface oxygen vacancy concentration in the LST powders. However, operation in fuel cell $\mathrm{H}_{2}$ /air environment results in a great decrease of the cell resistance (see Fig. 5 (a)), and the oxygen vacancies are observed to be significantly increased in the LST after the fuel cell measurement, see Fig. 7(c). This fact may well explain the large reduction of the cell resistance from the air to the $\mathrm{H}_{2}$ /air conditions, see Fig. 5(b).

Figure 9 presents an overview of the LST electrical properties and ionic conducting mechanism. Fig. 9(a) shows the total electrical conductivity change 
of the LST cell in the air/air and air/ $\mathrm{H}_{2}$ conditions, which are calculated using the EIS results shown in Figs. 5(a) and 5(b). The total electrical conductivity of the cell changed from $1.35^{*} 10^{-6} \mathrm{~S} \cdot \mathrm{cm}^{-1}$ in air/air, corresponding to an insulating state, to $0.221 \mathrm{~S} \cdot \mathrm{cm}^{-1}$ in air/ $\mathrm{H}_{2}$ after several minutes. A phase transformation induced by the fuel cell conditions presumably occurred in the amorphous shell of the LST particles. The $\mathrm{H}_{2}$ /air atmosphere reduces the formation energies of the oxygen vacancies in the amorphous shell of the LST electrolyte. ${ }^{36}$ The low oxygen vacancy formation energies of the space charge area make the incorporation of lattice oxygen more easily exchanged in the $\mathrm{H}_{2}$ /Air atmosphere, resulting in more oxygen vacancies formed in the amorphous shell of the LST, thus facilitating oxide-ion mobility.

In this case, the surfaces or boundaries of the LST particles are linked together to form a channel for oxide-ion transport in the fuel cell as shown in Fig. 9(b). As reported, the ionic conductivity of an oxide-ion conductor can be enhanced significantly by forming a heterostructure composite between the oxide-ion conductor and a semiconductor. ${ }^{37-38}$. The great enhancement of the ionic conductivity in YSZ/STO and YSZ-STO/SDC-STO heterostructure is an example of this effect. ${ }^{13-14}$ A similar situation can be applied for the LST. We consider the core-shell structure of the LST as a heterostructure consisting of an inner bulk LST semiconductor and an oxide-ion conducting amorphous surface layer which is filled by high oxygen vacancy defects. A remarkable enhancement of the oxide-ion conductivity for the LST is consequently facilitated. Recently, mounting evidence indicates that due to the strong correlation properties of transition metal oxides, the two-dimensional electronic 
states at their interfaces are very different from those of the conventional semiconductor interface. ${ }^{39}$ An interface superconducting phenomenon has attracted growing interest. $^{40}$. The most well-known example is the $\mathrm{LaAlO}_{3} / \mathrm{SrTiO}_{3}$ (LAO/STO) heterostructure, which is reported to show quasi-two-dimensional superconducting. ${ }^{40-42}$ A 'electronic reconstruction' based on the concept of 'polar catastrophe' in the two-dimensional electron gas (2DEG) at the LAO/STO interface was the most popular explanation. ${ }^{42-43}$ In present case, at the same LST particle forming under the fuel cell condition a heterostructure, i.e. an inherent insulating LST core covered by an amorphous LST layer of a few nm thick. The correlation between electrons and ions, (oxygen vacancies) has been recognized as a new scientific discipline of the Ionotronics. As pointed out: "It is an emerging technology that exploits the coupled ionic and electronic character of materials, including the profound modifications of structure, composition, and properties achievable through external fields”. ${ }^{44}$ Introduction of oxygen vacancies results in a shift of the conduction band to lower energies. The electron and ion coupling or correlation can play an influential effect on the new physical properties, e.g. superionic conductivity in LST because the formed ion defects can change the electron state to introduce new energy level in the electron band structure. ${ }^{45}$. Therefore, correlated energy band structure and oxygen defects may result in new physical phenomena, e.g. for the ionic transport which has not yet been well understood. It just starts as a new emerging fundamental subject to be carried out in our on-going research. Fig. 9(b) also presents a working principle of the LST electrolyte SOFC. It should be noted that the fuel cell environment is a prerequisite for the LST to be able to act as an oxygen ion conductor. It should 
be noticed that the in-plane electric fields inside the cell due to the potential difference between the anode and cathode may increase the oxygen vacancy concentration of the heterointerface between the surface amorphous layer and the bulk LST. ${ }^{36}$ The situation is also similar to that of the $\mathrm{CeO}_{2}$ nanosheaves, where an existing amorphous layer encapsulating the nanowire may serve as a fast conduction pathway. ${ }^{46}$. The $\mathrm{O}^{2-}$. can be transported through the interfaces' highways of the LST particles. The correlation or coupling between the electrons and the oxide ions transported in the amorphous shell of the LST surfaces can strongly facilitate the hydrogen oxidation reaction (HOR) and oxygen reduction reaction (ORR) and lead to high power outputs for the device using them.

\section{Conclusions}

A novel core-shell heterostructured LST has been discovered and demonstrated successfully for advanced LTSOFCs for the first time. This structure can be considered as a semiconductor core and superionic conducting surface layer heterostructure. The fuel cell $\mathrm{H}_{2} /$ air operation induced a superionic conduction phase transition from $10^{-6} \mathrm{~S} \cdot \mathrm{cm}^{-1}$ (corresponding to an almost insulating phase) into a superionic phase with the conductivity of 0.221 $\mathrm{S} \cdot \mathrm{cm}^{-1}$ at $550{ }^{\circ} \mathrm{C}$, corresponding to the conductivity enhancement by five orders of the magnitude. The correlation between electrons and oxide-ions (oxygen vacancies) in the core-shell heterostructure presents a new scientific mechanism for the LST superionic conduction and a new principle for advanced SOFCs. Unlike the conventional SOFC oxide ion structural bulk transport mechanism, the surface/interface highways constructed in the LST have demonstrated a new generation of high performance SOFCs at low 
temperatures, e.g., $908.2 \mathrm{~mW} \cdot \mathrm{cm}^{-2}$ at $550{ }^{\circ} \mathrm{C}$. This study provides strong evidence to support that the ionic transport properties at surfaces/boundaries can dominate the transport properties of the entire material when a sufficient content of boundaries and oxygen vacancies exists on the semiconductor particles. This work represents a new approach to design and develop advanced materials and devices for LT-SOFCs, helping to leverage the obvious advantages of the low cost for commercialization.

\section{Acknowledgements}

The authors thank the National Natural Science Foundation of China (No. 51302033), the Fundamental Research Funds for the Central Universities (No. N172504025), the Natural Science Foundation of Liaoning and Hubei Province (No. 2015020637 and 2015CFA120), the Swedish Research Council (Grant No. 621-2011-4983), and the European Commission FP7 TriSOFC-project (Grant No. 303454) for the financial support. The authors thank Mr. Kai Yu at School of Metallurgy of Northeastern University for assistance with the XRD and SEM measurements. The authors thank Mr. Yu Dong at New Materials Technology Research Institute of Northeastern University for assistance with the STEM measurements.

G.C. and B.Z. conceived and conducted the study and wrote the manuscript. H.D. fabricated the fuel cells and performed the tests. Y.L., W.S. and H.L synthesized powder material and performed the XPS, Raman, TGA, XRD and FTIR measurements. All authors discussed the results and commented on the manuscript.

\section{References}


(1) Goodenough, J.B. Oxide-ion conductors by design. Nature 1999, 404, 821-823.

(2) Yamamoto, O.; Arati, Y.; Takeda, Y.; Imanishi, N.; Mizutani, Y.; Kawai, M.;

Nakamura, Y. Electrical conductivity of stabilized zirconia with ytterbia and Scandia. Solid State Ionics 1995, 79, 137-142.

(3) Varanasi, C.; Juneja, C.; Chen, C.; Kumar, B.; Electrical conductivity enhancement in heterogeneously doped scandia-stabilized zirconia. J. Power Sources 2005, 147, 128-135.

(4) Mogensen, M.; Sammes, N.M.; Tompsett, G.A. Physical, Chemical and electrochemical properties of pure and doped ceria. Solid State Ionics 2000, 129, 63-94.

(5) Lee, D.; Han, J.H.; Chun, Y.; Song, R.H.; Shin, D.R. Preparation and characterization of strontium and magnesium doped lanthanum gallates as the electrolyte for IT-SOFC. J. Power Sources 2007, 166, 35-40.

(6) Shao, Z.; Haile, S.M. A high-performance cathode for the next generation of solid-oxide fuel cells. Nature 2004, 431, 170-173.

(7) Tao, S.; Irvine, J.T.S. A redox-stable efficient anode for solid-oxide fuel cells. Nat. Mater. 2003, 2, 320-323.

(8) Suzuki, T.; Hasan, Z.; Funahashi, Y.; Yamaguchi, T.; Fujishiro, Y.; Awano, M. Impact of Anode Microstructure on Solid Oxide Fuel Cells. Science 2009, 325, 852-855.

(9) Evans, A.; Martynczuk, J.; Stender, D.; Schneider, C.W.; Lippert, T.; Prestat, M. Low-Temperature Micro-Solid Oxide Fuel Cells with Partially Amorphous $\mathrm{La}_{0.6} \mathrm{Sr}_{0.4} \mathrm{CoO}_{3-\delta}$. Cathodes. Adv. Energy Mater. 2000, 288, 2031-2033. 
(10) Iwanschitz, B.; Sfeir, J.; Mai, A.; Schütze, M. Degradation of SOFC anodes upon redox cycling: a comparison between Ni/YSZ and Ni/CGO. J. Electrochem. Soc. 2010, 157, B269-278.

(11) Waldbillig, D.; Wood, A.; Ivey, D.G. Electrochemical and microstructural characterization of the redox tolerance of solid oxide fuel cell anodes. J. Power sources 2005, 145, 206-215.

(12) Timurkutluk, B.; Timurkutluk, C.; Mat, M.D.; Kaplan, Y. A review on cell/stack designs for high performance solid oxide fuel cells. Renew. Sust. Energ. Rev. 2016, $56,1101-1121$.

(13) Garcia-Barriocanal, J.; Rivera-Calzada, A.; Varela, M.; Sefrioui, Z.; Iborra, E.; Leon, C.; Pennycook, S.J.; Santamaria, J. Colossal Ionic Conductivity at Interfaces of Epitaxial $\mathrm{ZrO}_{2}: \mathrm{Y}_{2} \mathrm{O}_{3} / \mathrm{SrTiO}_{3}$ Heterostructures. Science 2008, 321, 676-680.

(14) Lee, S.; Zhang, W.; Khatkhatay, F.; Wang, H.; Jia, Q.; MacManus-Driscoll, J.L. Ionic Conductivity Increased by Two Orders of Magnitude in Micrometer-Thick Vertical Yttria-Stabilized $\mathrm{ZrO}_{2}$ Nanocomposite Films. Nano Lett. 2015, 15, 7362-7369.

(15) Maier, J. Nanoionics: ion transport and electrochemical storage in confined systems. Nat. Mater. 2005, 4, 805-815.

(16) Haverkate, L.A.; Chan, W.K.; Mulder, F.M. Large Space-Charge Effects in a Nanostructured Proton Conductor. Adv. Funct. Mater. 2010, 20, 4107-4116.

(17) Lan, R.; Tao, S. Novel Proton Conductors in the Layered Oxide Material $\mathrm{Li}_{\mathrm{x}} \mathrm{IAl}_{0.5} \mathrm{Co}_{0.5} \mathrm{O}_{2}$. Adv. Energy. Mater. 2014, 4, 1301683.

(18) Zhou, Y.; Guan, X.; Zhou, H.; Ramadoss, K.; Adam, S.; Liu, H.; Lee, S.; Shi, J.; Tsuchiya, M.; Fong, D.D.; S. Ramanathan. Strongly correlated perovskite fuel cells. Nature 2016, 534, 231-234. 
(19) Zhu, B.; Raza, R.; Abbas, G.; Sing, M. An Electrolyte-Free Fuel Cell Constructed from One Homogenous Layer with Mixed Conductivity. Adv. Func. Mater. 2011, 21, 2465-2469.

(20) Zhu, B.; Raza, R.; Qin, H.; Liu, Q.; Fan, L. Fuel cells based on electrolyte and non-electrolyte separators. Energy Environ. Sci. 2011, 4, 2986-2992.

(21) Fan L.; Wang C.; Chen M.; Zhu B.; Recent development of ceria-based (nano)composite materials for low temperature ceramic fuel cells and electrolyte-free fuel cells. J. Power Sources 2013. 234,154-174.

(22) Zhang G.; Li W.; Huang W.; Cao Z.; Shao K.; Li F.; Tang C.; Li C.; He C.; Zhang Q.; Fan L. Strongly coupled $\mathrm{Sm}_{0.2} \mathrm{Ce}_{0.8} \mathrm{O}_{2}-\mathrm{Na}_{2} \mathrm{CO}_{3}$ nanocomposite for low temperature solid oxide fuel cells: One-step synthesis and super interfacial proton conduction. J. Power Sources 2018, 386, 56-65.

(23) Chen, G.; Qian, Y.; Liu, M.; Ma, W.; Geng, S.; Meng, X.; Yu, K.; Liu, G. Investigation of chemical compatibility between B-site doped La substituted $\mathrm{SrTiO}_{3}$ anode and stabilized zirconia electrolyte. J. Power Sources 2016, 328, 212-218.

(24) Chen, G.; Kishimoto, H.; Yamaji, K.; Kuramoto, K.; Horita, T. Effect of Interaction between A-Site Deficient LST and ScSZ on Electrochemical Performance of SOFC. J. Electrochem. Soc. 2015, 162, F223- F228.

(25) Maier, J. Ionic Conduction in Space Charge Regions. Prog. Solid State Chem. 1995, 23, 171-263.

(26) Sata, N.; Eberman, K.; Eberl, K.; Maier, J. Mesoscopic Fast Ion Conduction in Nanometre-Scale Planar Heterostructures. Nature 2000, 408, 946-949.

(27) Fan L.; Zhu B.; Su P.C.; He C. Nanomaterials and technologies for low temperature solid oxide fuel cells: Recent advances, challenges and opportunities. Nano Energy 2018, 45, 148-176. 
(28) Chen, G.; Sun, W.; Luo, Y.; Liu, H.; Geng, S.; Yu, K.; Liu, G. Investigation of layered $\mathrm{Ni}_{0.8} \mathrm{Co}_{0.15} \mathrm{Al}_{0.05} \mathrm{LiO}_{2}$ in electrode for low-temperature solid oxide fuel cells. Int. J. Hydro. Energy 2018, 43, 417-425.

(29) Ruiz-Morales, J.C.; Canales-Vázquez, J.; Savaniu, C.; Marrero-López, D.; Zhou, W.; Irvine, J.T.S. Disruption of extended defects in solid oxide fuel cell anodes for methane oxidation. Nature 2006, 439, 568-571.

(30) Marina, O.A.; Canfield, N.L.; Stevenson, J.W. Thermal electrical, and electrocatalytical properties of lanthanum-doped strontium titanate. Solid State Ionics 2002, 149, 21-28.

(31) Xia, C.; Wang, B.Y.; Ma, Y.; Cai, Y.X.; Afzal, M.; Liu, Y.Y.; He, Y.J.; Zhang, W.; Dong, W.J.; Li, J.J.; Zhu, B. Industrial-grade rare-earth and perovskite oxide for high-performance electrolyte layer-free fuel cell. J. Power Sources 2016, 307, 270-279.

(32) Li, X.; Zhao, H.; Xu, N.; Zhou, X.; Zhang, C.; Chen, N. Electrical conduction behavior of $\mathrm{La}$, Co co-doped $\mathrm{SrTiO}_{3}$ perovskite as anode material for solid oxide fuel cells. Int. J. Hydro. Energy 2009, 34, 6407-6414.

(33) Fuentes, S.; Céspedes, F.; Padilla-Campos, L.; Diaz-Droguett, D.E. Chemical and structural analysis related to defects in nanocrystalline $\mathrm{Ba}_{1-\mathrm{x}} \mathrm{Sr}_{\mathrm{x}} \mathrm{TiO}_{3}$ grown via hydrothermal sol-gel. Ceram. Int. 2014, 40, 4975-4984.

(34) Yao, D.; Zhou, X.; Ge, S. Raman scattering and room temperature ferromagnetism in Co-doped $\mathrm{SrTiO}_{3}$ particles. Appl. Surf. Sci. 2011, 257, 9233-9236. (35) Wannasen, L.; Swatsitang, E. Magnetic properties dependence on $\mathrm{Fe}^{2+} / \mathrm{Fe}^{3+}$ and oxygen vacancies in $\mathrm{SrTi}_{0.95} \mathrm{Fe}_{0.05} \mathrm{O}_{3}$ nanocrystalline prepared by hydrothermal method. Microelectron. Eng. 2015, 146, 92-98. 
(36) Veal, B.W.; Kim, S.K.; Zapol, P.; Iddir, H.; Baldo, P.M.; Eastman, J.A. Interfacial control of oxygen vacancy doping and electrical conduction in thin film oxide heterostructures. Nat. commun. 2015, 7, 11892.

(37) Zhu, B.; Huang, Y.; Fan, L.; Ma, Y.; Wang, B.; Xia, C.; Afzal, M.; Zhang, B.; Dong, W.; Wang, H.; Lund, P.D. Novel fuel cell with nanocomposite functional layer designed by perovskite solar cell principle. Nano Energy 2016, 19, 156-164.

(38) Dong, W.; Yaqub, A.; Janjua, N.K.; Raza, R.; Afzale, M.; Zhu, B. All in One Multifunctional Perovskite Material for Next Generation SOFC. Electrochim. Acta 2016, 193, 225-230.

(39) Mannhart, J.; Schlom, D.G. Oxide Interfaces-An Opportunity for Electronics. Science 2010, 327, 1607-1611.

(40) Reyren, N.; Thiel, S.; Caviglia, A.D.; Fitting Kourkoutis, L.; Hammerl, G.; Richter, C.; Schneider, C.W.; Kopp, T.; Rüetschi, A.S.; Jaccard, D.; Gabay, M.; Muller, D.A.; Triscone, J.M.; Mannhart, J. Superconducting interfaces between insulating oxides. Science 2007, 317, 1196-1199.

(41) Hwang, H. Y.; Iwasa, Y.; Kawasaki, M.; Keimer, B.; Nagaosa, N.; Tokura, Y. Emergent phenomena at oxide interfaces. Nat. Mater. 2012, 11, 103-113.

(42) Bristowe, N. C.; Ghosez, P.; Littlewood, P. B.; Artacho, E. The origin of twodimensional electron gases at oxide interfaces: insights from theory. J. Phys-Condens. Mat. 2014, 14, 143201.

(43) Nakagawa, N.; Hwang, H.; Muller, D. Why some interfaces cannot be sharp. Nat. Mater. 2006, 5, 204-209.

(44) Fong, D. D.; Ramanathan, S. Preface for Special Topic: Ionotronics. Apl Mater. 2017, 5, 042201. 
(45) Oshime N.; Kano J.; Ikeda N.; Teranishi T.; Fujii T.; Ueda T.; Ohkubo T. Quantitative study of band structure in $\mathrm{BaTiO}_{3}$ particles with vacant ionic sites. $J$. Appl. Phys. 2016, 120, 154101.

(46) Kim, S.; Lee, J.S.; Mitterbauer, C.; Ramasse, Q.M.; Sarahan, M.C.; Browning, N.D.; Park, H.J. Anomalous Electrical Conductivity of Nanosheaves of $\mathrm{CeO}_{2}$. Chem. Mater. 2009, 21, 1182-1186. 

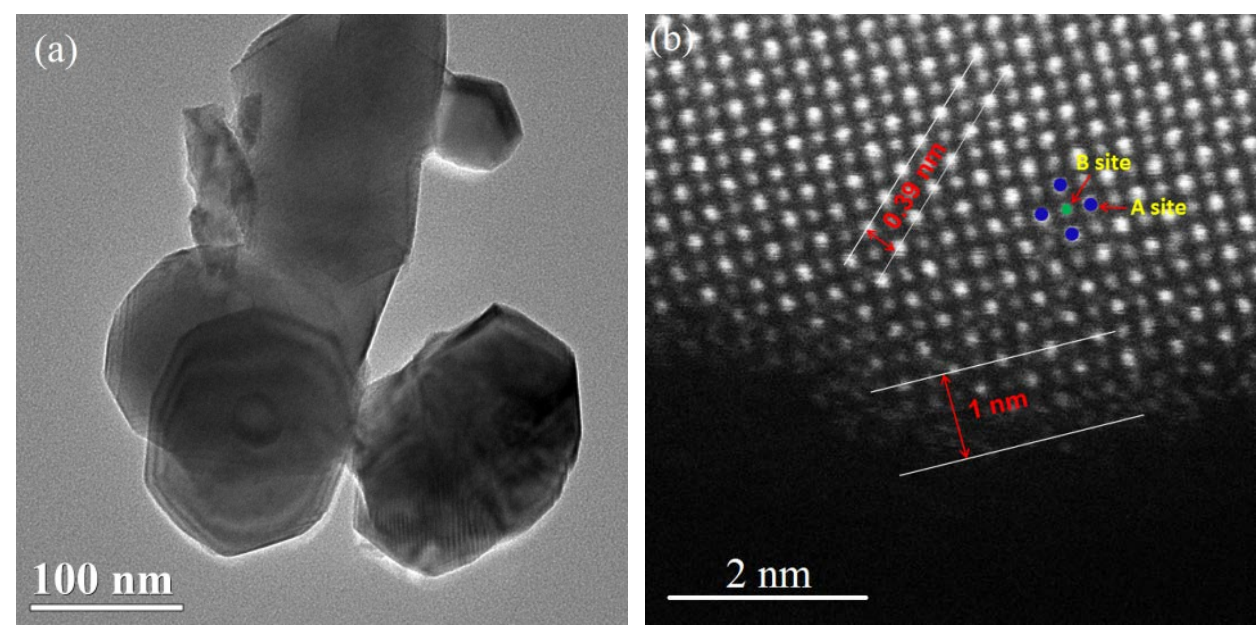

(c)
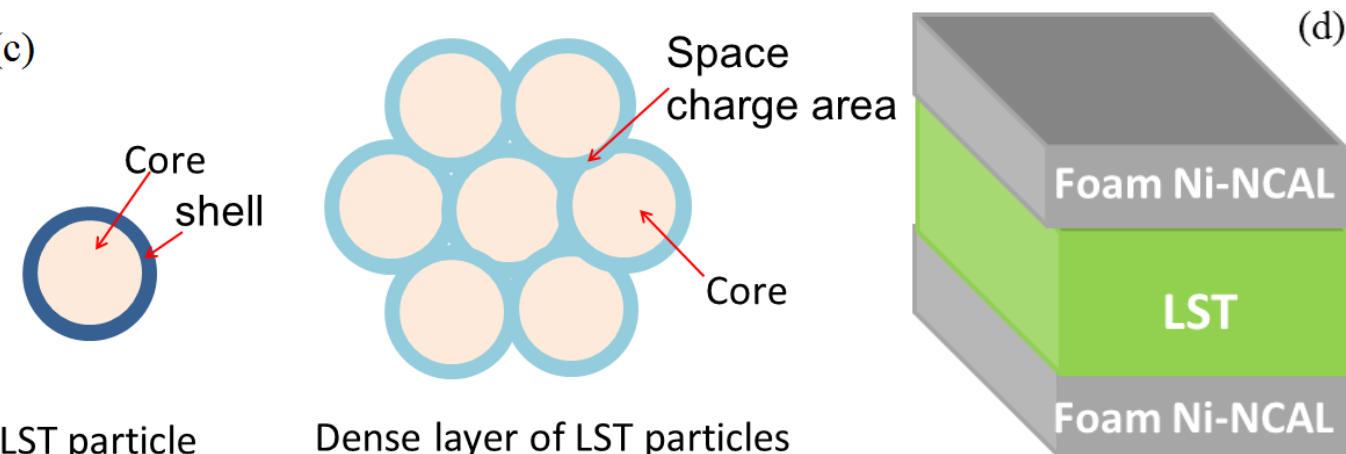

LST particle

Dense layer of LST particles

(d)

Figure 1 (a) TEM image of 2 h LST powder, (b) HAADF-STEM image of 2 h LST powder, (c) schematic of the core-shell structure of the LST particle and the space charge area in the compacted LST layer, and (d) diagram of the symmetrical cell with the Ni foam-NCAL/LST/NCAL-Ni foam structure 


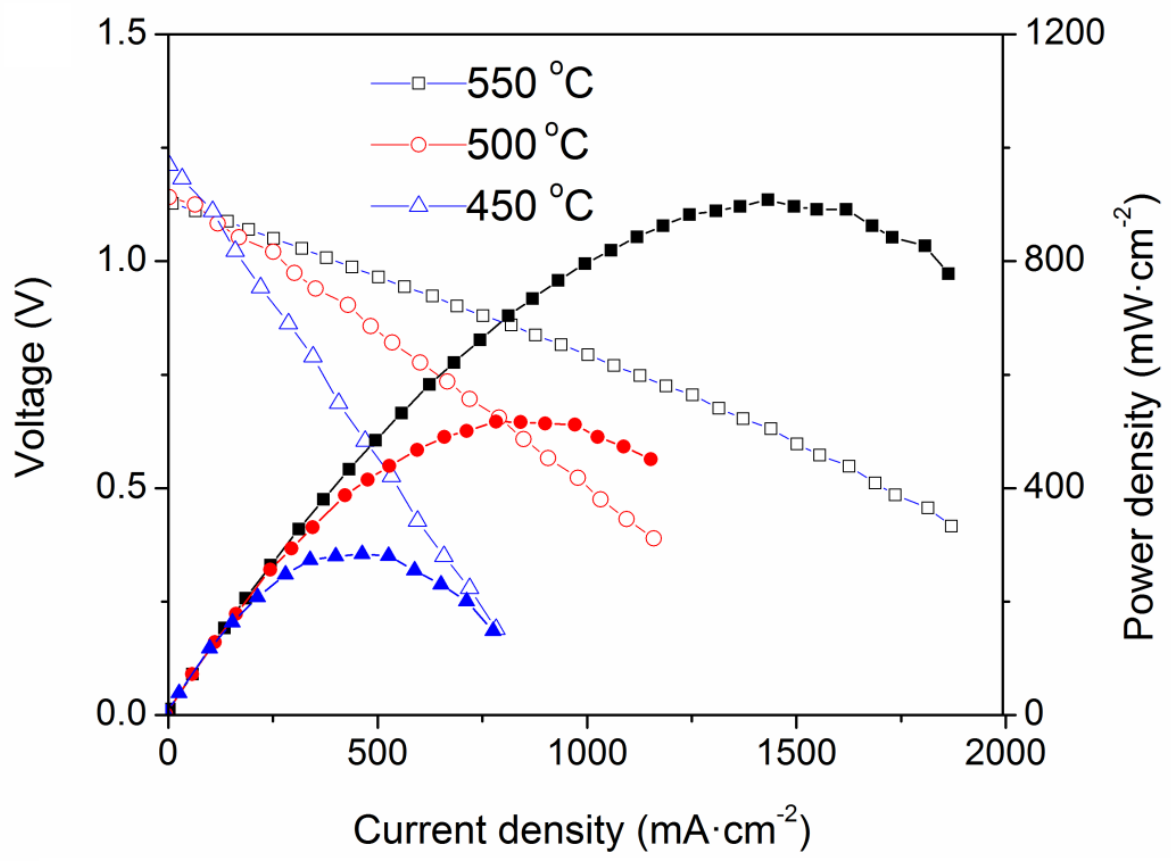

Figure $2 \mathrm{I}-\mathrm{V} / \mathrm{I}-\mathrm{P}$ curves of the cell operated at 550, 500 and $450{ }^{\circ} \mathrm{C}$ in $\mathrm{H}_{2}$ 


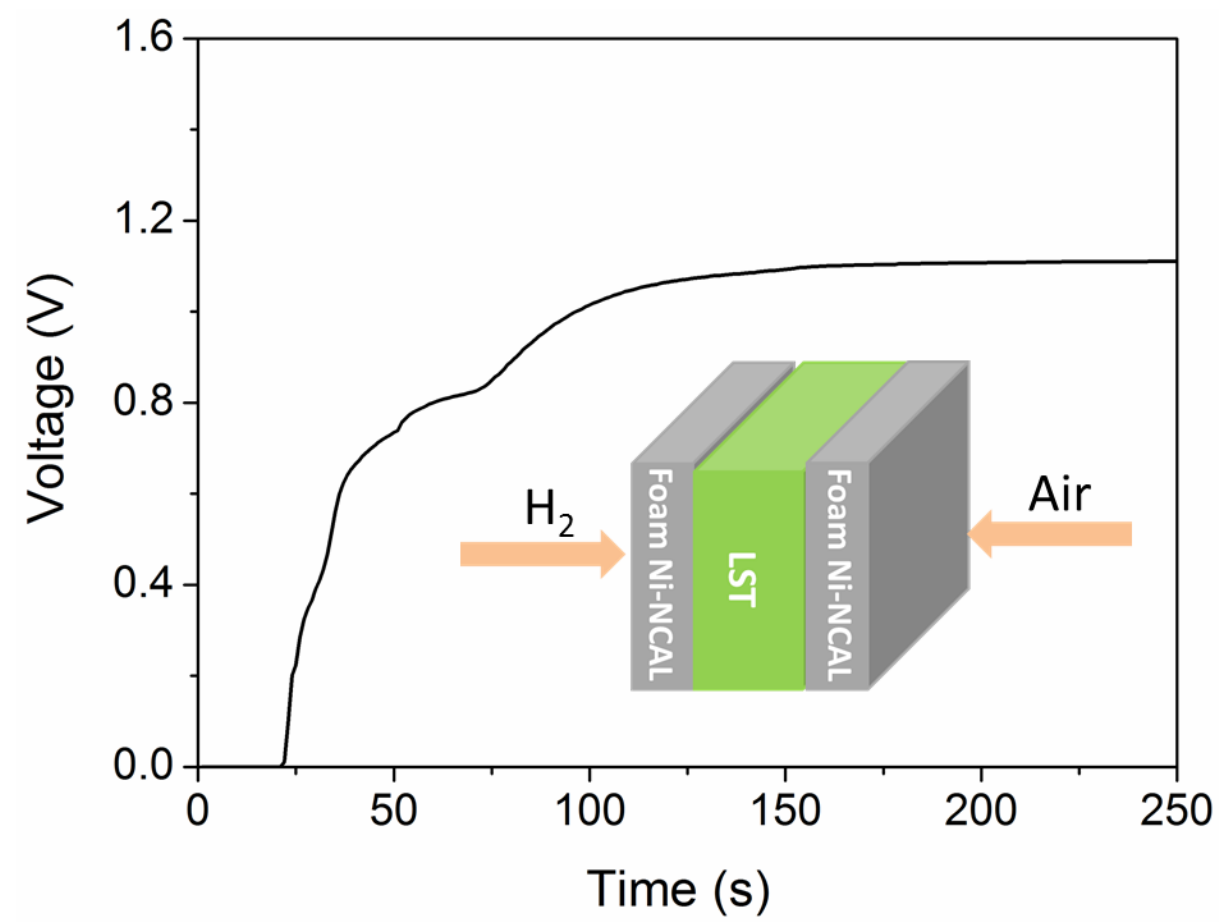

Figure $3 \mathrm{OCV}$ changes with time after pure $\mathrm{H}_{2}$ and air were flowed into both sides of the cell with the LST electrolyte (the flow rates of $\mathrm{H}_{2}$ and air were both $100 \mathrm{ml} / \mathrm{min}$ ) 


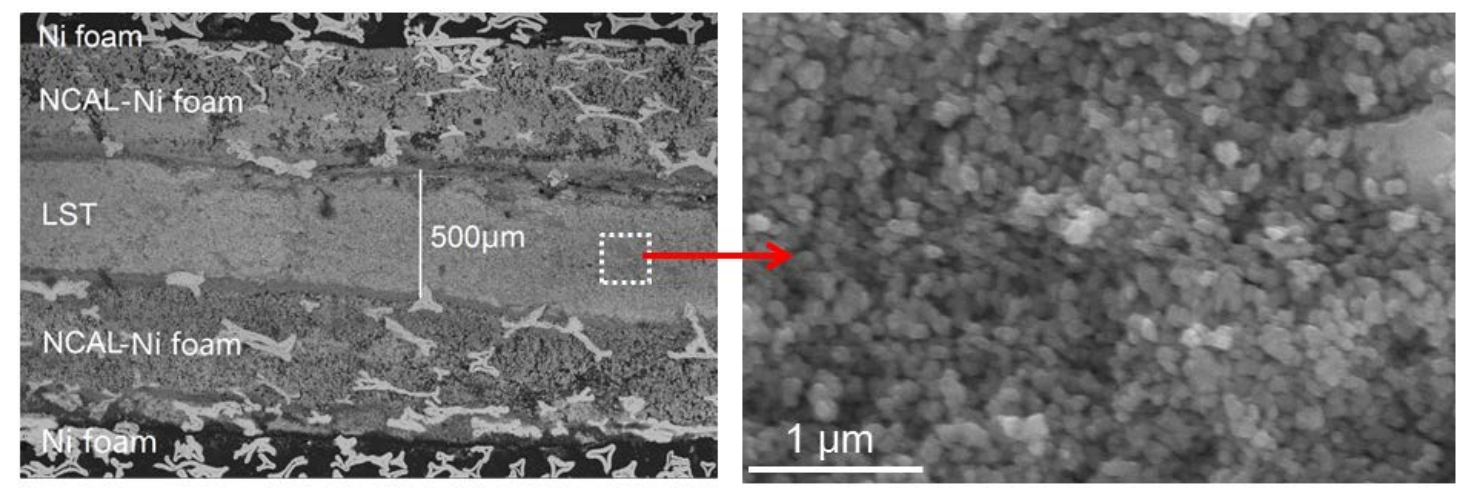

Figure 4 SEM images of the cross section of the symmetrical cell and the magnified image of the LST electrolyte 
(a)

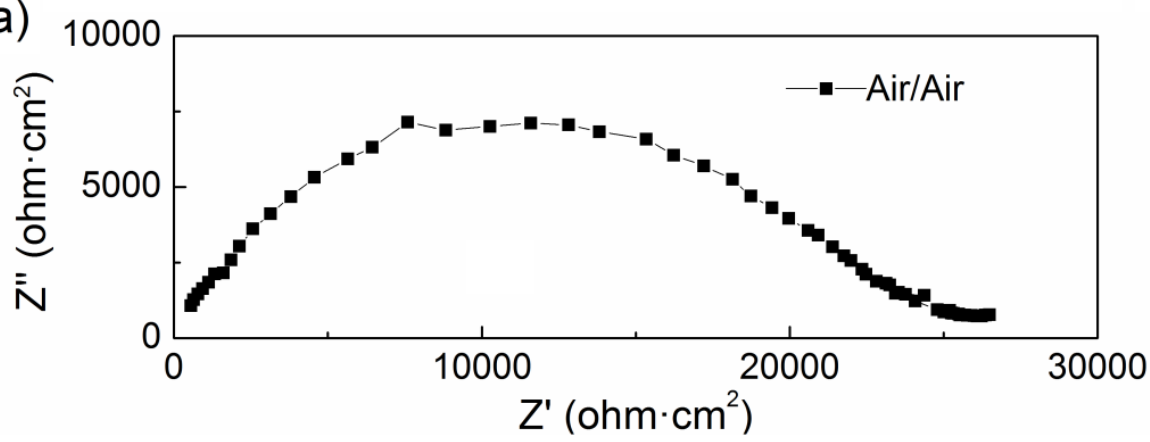

(b)

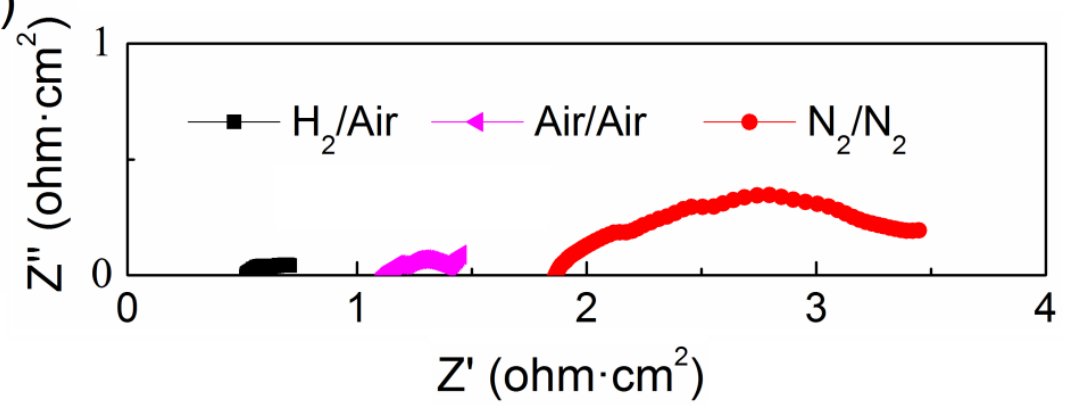

Figure 5 (a) impedance spectra of the cell operated at $550{ }^{\circ} \mathrm{C}$ with air in both sides before the performance test in $\mathrm{H}_{2}$, and (b) impedance spectra of the cell operated at $550{ }^{\circ} \mathrm{C}$ with $\mathrm{H}_{2}$ /air, $\mathrm{N}_{2} / \mathrm{N}_{2}$ and air/air sequentially (each pair of gases is flowed for $1 \mathrm{~h}$ for the EIS test) 


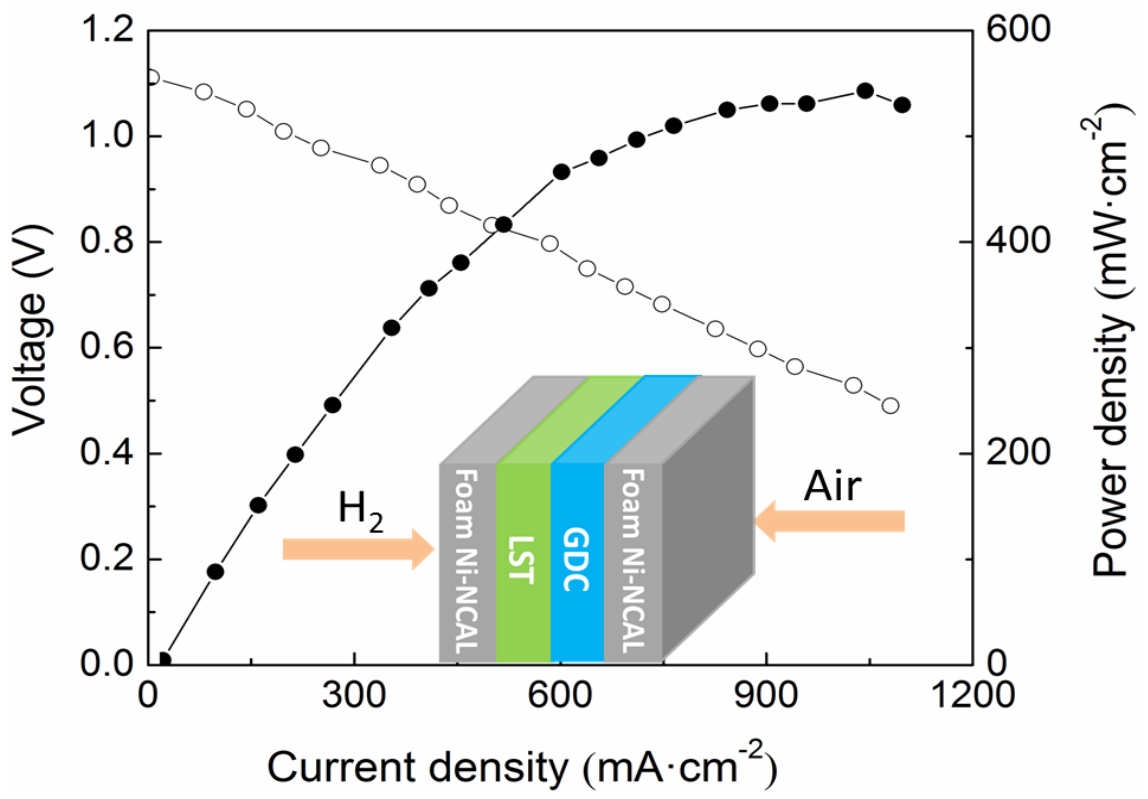

Figure 6 IV-IP curve of the cell with the bi-layered LST/GDC electrolyte and the corresponding schematic illustration of the cell 

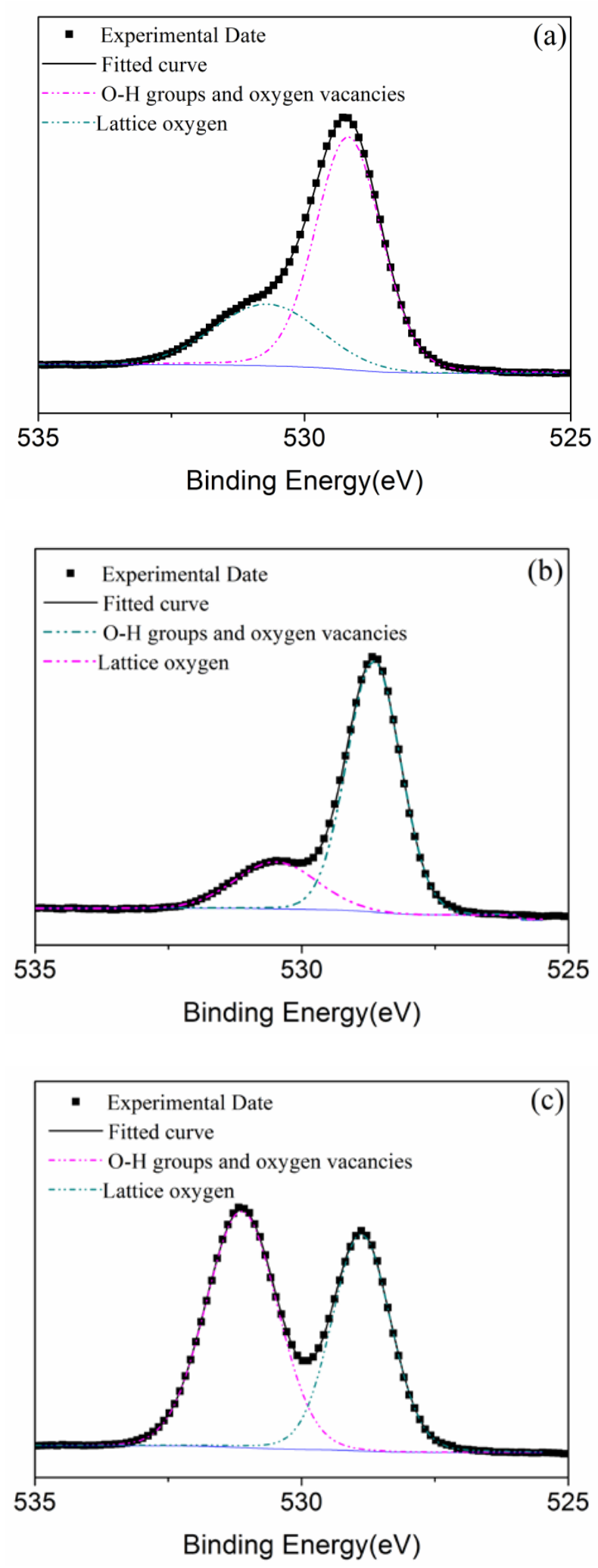

Figure 7 (a) O1s XPS spectra of the as-prepared LST powder, (b) O1s XPS spectra of the LST powder after reduction in $\mathrm{H}_{2}$ at $550{ }^{\circ} \mathrm{C}$ for $2 \mathrm{~h}$, (c) O1s XPS spectra of the LST powder scraped from the cell after the fuel cell measurements 

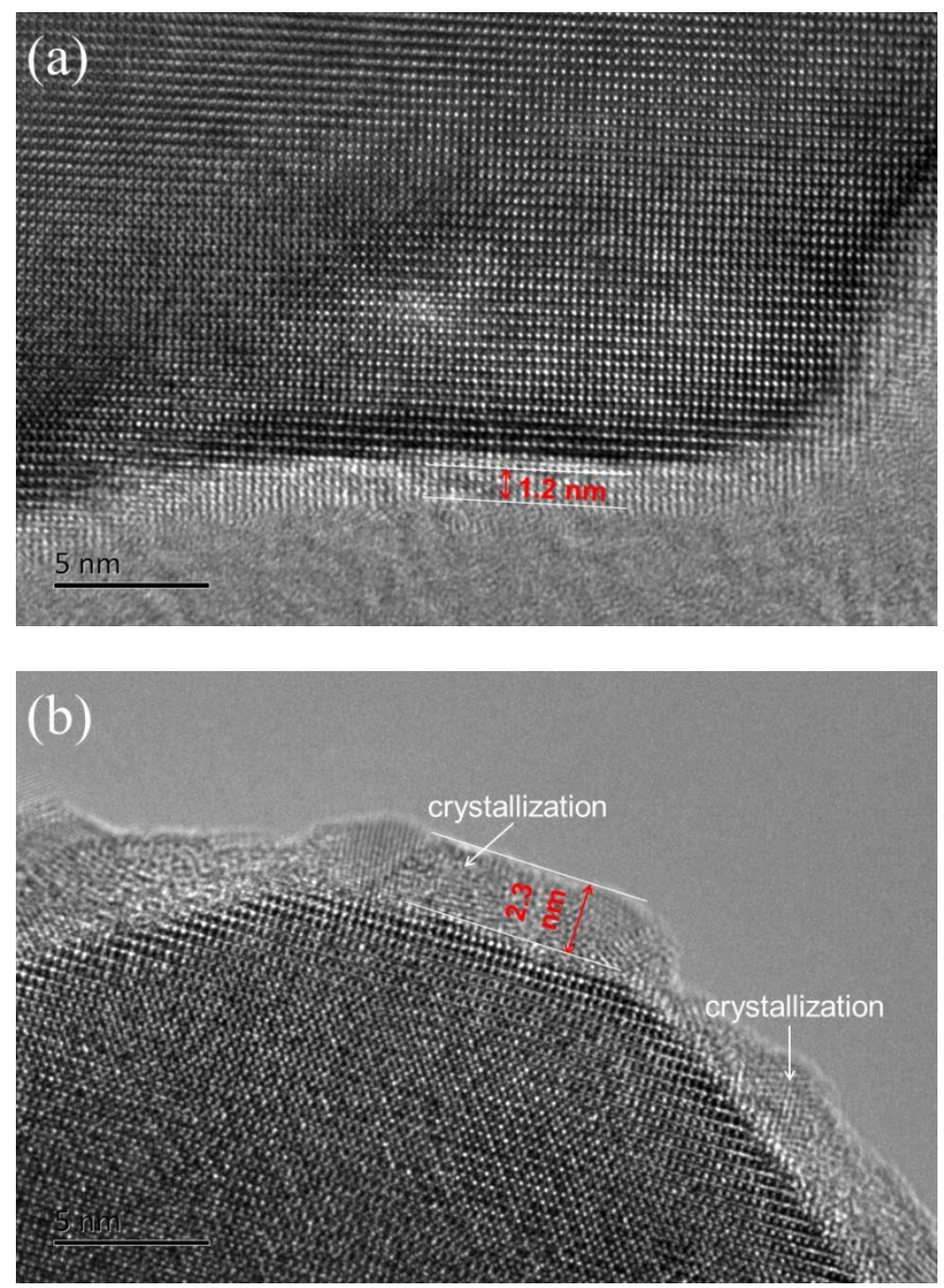

Figure 8 HRTEM images of LST powder before and after performance test, (a) raw powder, (b) LST powder scraped from the cell after the fuel cell performance test 


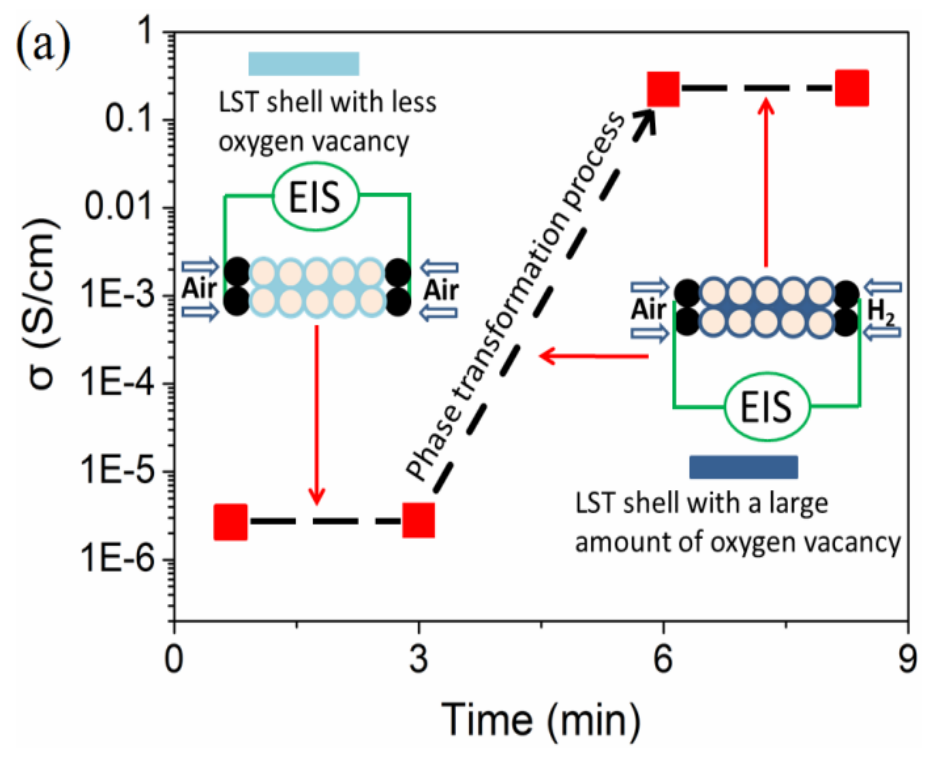

(b) icathode'

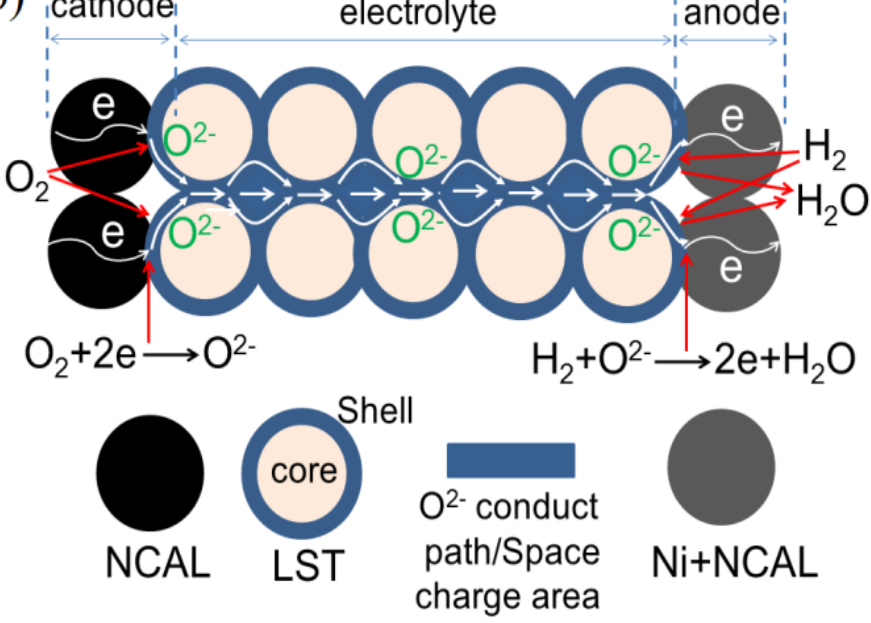

Figure 9 (a) Total electrical conductivity of the cell with the LST electrolyte in air/air and in air/ $\mathrm{H}_{2}$ and (b) schematic of the electrochemical reaction mechanism at the electrode and the oxygen ion transport mechanism in the cell with the LST electrolyte 